6. Miehle K, Paschke R, Koch CA. Citalopram therapy as a risk factor for symptomatic hyponatremia caused by the syndrome of inappropriate secretion of antidiuretic hormone (SIADH): a case report. Pharmacopsychiatry 2005; 38: 181-182.

7. Roehr J, Woods A, Corbett R, Kongsamut S. Changes in paroxetine binding in the cerebral cortex of polydipsic rats. Eur $J$ Pharmacol 1995; 278: 75-78.

8. Mittleman G, Rosner AL, Schaub CL. Polydipsia and dopamine: behavioural effects of dopamine D1 and D2 receptor agonists and antagonists. J Pharmacol Exp Ther 1994; 271: 638650 .

9. Assouly-Besse F, Seletti B, Lamarque I, Eighozi D, Petitjean F. Le syndrome polydipsie, hyponatrémie intermittence et psychoses: diagnotic et conduite thérapeutique à propos d'un cas. Ann Med Psychol 1996; 154: 259-263.
10. Spears NM, Leadbetter RA, Shutty MS, Jr. Clozapine treatment in polydipsia and intermittent hyponatremia. J Clin Psychiatry 1996; 57: 123-128.

11. McMichael AJ, Woodruff RE, Hales S. Climate change and human health: present and future risks. Lancet 2006; 367: 859-869.

Dr Claudia Stöllberger MD Univ. Prof. Josef Finsterer MD, PhD Krankenanstalt Rudolfstiftung, Wien, Austria

Published online in Wiley InterScience (www.interscience.wiley.com) DOI: $10.1002 /$ pds. 1456

\title{
Re: Use of cyclo-oxygenase 2 inhibitors (COX-2) and prescription non-steroidal anti-inflammatory drugs (NSAIDS) in UK and USA populations: implications for COX-2 cardiovascular profile
}

To the Editor

We read the paper by Arellano et al. describing the channelling of cyclo-oxygenase 2 inhibitors (COX-2) and non-steroidal anti-inflammatory drugs (NSAIDs) in UK and USA populations ${ }^{1}$ using databases they describe as generally thought to be representative. The authors report on the characteristics of patients using COX-2 and NSAIDs, including history of upper gastrointestinal events and cardiovascular disease. Our comments relate solely to the UK data as some of their results differ remarkably from data in the General Practice Research Database (GPRD); the database considered to be the UK gold standard. It raises again the issues of quality and completeness of the data from
The Health Improvement Network (THIN). The table shows the differences in results between GPRD and THIN. Although Arellano et al. did not share their exact codes with us we based our coding on the textual list of events provided in the paper.

Our results indicate issues of missing data and changes over calendar time in time. A previous report has suggested considerable differences within THIN of the incidence rate of fractures. ${ }^{2}$ This may be related to the lack of quality criteria for inclusion of data into THIN. As an example of how GPRD ensures quality, $11 \%$ of the practices that sent data to the GPRD are not used as the data do not meet quality standards. ${ }^{3}$ Also, some of the practices that contribute data to THIN may be new to the VISION IT software and clinical data

\begin{tabular}{|c|c|c|c|c|c|c|c|c|}
\hline & \multicolumn{2}{|c|}{ Ibuprofen } & \multicolumn{2}{|c|}{ Diclofenac } & \multicolumn{2}{|c|}{ Rofecoxib } & \multicolumn{2}{|c|}{ Celecoxib } \\
\hline & THIN $^{*}$ & GPRD & THIN & GPRD & THIN $^{*}$ & GPRD & THIN $^{*}$ & GPRD \\
\hline No. of patients & 141608 & 485103 & 187558 & 498234 & 28274 & 44109 & 29363 & 37914 \\
\hline Ratio GPRD/THIN & & 3.4 & & 2.7 & & 1.6 & & 1.3 \\
\hline Average calendar year & & 1998 & & 1999 & & 2001 & & 2002 \\
\hline Percentage history of thrombolic events & 7.0 & 10.4 & 6.0 & 9.1 & 13.9 & 23.1 & 14.1 & 24.7 \\
\hline Percentage history of gastrointestinal events & 0.2 & 2.5 & 0.2 & 2.9 & 0.7 & 7.7 & 0.7 & 7.5 \\
\hline
\end{tabular}


from previous software may not convert correctly to the VISION IT software. The amount of practices contributing data to THIN has changed considerably over time (considerably more than the changes in GPRD), suggesting substantial changes over calendar time in the amount of data in THIN.

As the utilisation of the various NSAIDs did change over time, Arellano et al. should have considered and adjusted for any changes over time in the amount and lower quality of THIN data. Channelling over time of drugs in actual clinical practice should be studied but require high quality data that are complete over time.

\section{REFERENCES}

1. Arellano FM, Yood MU, Wentworth CE, et al. Use of cyclo-oxygenase 2 inhibitors (COX-2) and prescription non- steroidal anti-inflammatory drugs (NSAIDS) in UK and USA populations. Implications for COX-2 cardiovascular profile. Pharmacoepidemiol Drug Saf 2006; 15: 861-872.

2. van Staa TP, Geusens P, Pols HA, de Laet C, Leufkens HG, Cooper C. A simple score for estimating the long-term risk of fracture in patients using oral glucocorticoids. QJM 2005; 98(3): 191-198.

3. General Practice Research Database http://www.gprd. com/_docs/GPRDPracticePatientPopulations.pdf [downloaded August 8, 2007].

TJeERd P. van StaA

J. PARKINSON

GPRD, MHRA, London, UK

Published online in Wiley InterScience

(www.interscience.wiley.com)

DOI: $10.1002 /$ pds. 1478 